\title{
COMBATING TERRORISM IN THE EUROPEAN UNION AND THE REPUBLIC OF POLAND
}

\begin{abstract}
International terrorism is one of the most serious threats to global security nowadays. Countries that struggle with problems such as respecting democracy and human rights, as well as free market economy are especially threatened by terrorism.

Strong separatist tendencies as well as national, religious, social and race divisions are the significant factor influencing the development of terrorism.

The scale of this phenomenon often goes beyond the borders of individual countries or regions becoming the global dimension threat.

Due to complexity of the problem one should consider it to be the permanent element in international politics.
\end{abstract}

Keywords: security, terrorism, human rights, European Union, The Republic of Poland's security policy.

\section{INTRODUCTION}

One of the most important human needs is safety. Stanisław Kawula states: "A need for safety is among the most important primary human needs, and a need for impact on the course of current events and their own faith among the psychosocial needs" (Kawula, 1999).

Safety needs become predominant for a person right after the physiological ones in Maslov's hierarchy of needs (Maslow, 1986).

Comprehensive personality development can be achieved by living in a full sense of security. Only concise personality makes an integrated psychophysical and moral whole with full human rights. A human being constituting the highest value as a social and independent individual should never become an object, tool or a means to achieve a goal by someone else (Stefański, 2003).

A need for security is an underestimated psychological and social value. It almost becomes an aim of human aspiration, and hence it is often a bargaining chip or a social engineering tool in social and political life. Lack of security introduces chaos, frustration, and hopelessness of life aims set in advance (Tomaszewski, 2001). All the activities which may bring to undermine the plans of terrorist acts cannot be overestimated, because it always involves/it is always about the highest value which is life. It can be acknowledged that prevention of criminal offences, especially terrorist attempts, requires particular care/ is of

\footnotetext{
1 Jolanta Puacz-Olszewska, PhD, Rzeszów University of Technology, Faculty of Management, Department of Security Science, ul. Powstańców Warszawy 12, 35-959 Rzeszów; e-mail: j.puacz@ prz.edu.pl; ORCID: 0000-0002-8034-4502.
} 


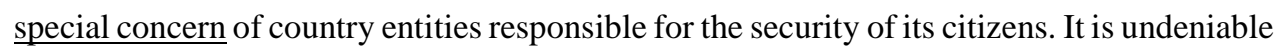
that terrorism is a problem of maximum alert level for societies of various country governments.

\section{ACTION OF THE EUROPEAN UNION IN ORDER TO COMBAT TERRORISM}

A catalyst for cooperation of the states in terms of internal security was the occurrence and the rise of terrorism. Terrorism, which then posed a special challenge, forced members of the European Economic Community to exchange information connected with terrorist activity regularly. This situation was the reason for establishing, in 1975, an organization called TREVI, which was responsible for coordination of activities and prevention of terrorism (Bukowski, 2010).

Protection of the borders of the European Economic Community and transmission of information concerning acts of terrorism to police forces of the Member States are its task. There was also cooperation within the framework of the Police Working Group on Terrorism, the European Political Cooperation Working Group and Schengen Group.

The decision of the creation of the European Police Office (Europol) was taken during the ministerial meeting of the TREVI organization.

The adoption of the Maastricht Treaty (Treaty on European Union) meant including the police cooperation in the Third Pillar of the European Union - the cooperation in the fields of justice and home affairs. Under the Treaty of the European Union, police cooperation in order to prevent and combat terrorism, drug trafficking, other forms of international crime as well as implementation of the system of exchange of information within the framework of the European Police Office (Europol) became a subject of interest of the Member States (http://www.uniaeuropejska.org/europo).

In the Treaty of Nice, reference in turn was made to the body of prosecution cooperation of the European Union, that is, Eurojust. There is an European Union agency dealing with prosecution, detection and detention, and making accusations.

The cooperation of the European states in the fight with against terrorism is determined by the process of the European integration. However, the coordination of activities between the Member States and the bodies of the European Union was considered as very bad, and introduction of anti-terrorist measures as slow. Three dates, which have had far-reaching impacts on the European Union cooperation in terms of combating terrorism need to be pointed out. There are: $11^{\text {th }}$ September 2001 ( attacks in the USA, $11^{\text {th }}$ March 2004 (attacks in Spain) and $7^{\text {th }}$ and $21^{\text {st }}$ July 2005 (attacks in London).

The adoption of legal and political instruments, the establishment of new structures, the shift in the emphasis in the European political debate were the products of this cooperation. The Justice and Home Affairs Council on $1^{\text {st }}-2^{\text {nd }}$ December 2005 and the European Council on $15^{\text {th }}-16^{\text {th }}$ December 2005 summarized the state of the cooperation when two programming documents: the EU 's Counter-Terrorism Strategy and the European Union Strategy for Countering Radicalisation and. Recruitment were adopted (Bukowski, 2010).

The consequences of the attacks in London and Madrid, was a noticeable signal to indicate that the terrorist issue inside the European Union was inappropriate. Therefore, after those events, the European Union intensified contacts with either regional or global international institutions that aims to combat terrorism. These groups include: the European Council, the United Nations (UN), the North Atlantic Treaty Organization (NATO), the 
Organization for Security and Co-operation in Europe (OSCE), the Western European Union (WEU), the African Union (AU), the Association of Southeast Asian Nations.

In response to the provisions of the United Nations Security Council Resolution 1373 (2001), the Union got involved, among other things, in: work of counter-terrorist teams under the protectorate of the United Nations, discussing issues totally backed by the Member States of the European Union; promoting universal anti-terrorist legal acts created by the system of the United Nations which consists of thirteen universal anti-terrorist together with additional protocols and the directional United Nations Security Council Resolutions; supporting the work on the newest document developed by the United Nations, that is, the UN Global Counterterrorism Strategy (http://www.cbnt.collegium.edu.pl/index.php? option=com...).

The European Union cooperates with other third countries, and Canada, Australia, Japan, Russia, Israel and especially the USA are its biggest partners. Apart from this, the European Committee prepares EU aid schemes and projects with: Pakistan, the Philippines, Indonesia, Morocco, Algeria, Kenya, Jordan, Afghanistan, Iraq. These projects aim to combat organized crime and terrorism. The Union aids them in the development of multi-level instruments such as judicial and police cooperation, border surveillance, combating terrorist financing, combating the illicit trade in arms, non-proliferation of weapons of mass destruction (WMD).

The EU strategy in the field of fighting terrorism concerns:

1. preventing terrorist threats,

2. protection against terrorist threats,

3. prosecution of perpetrators of terrorist attempts,

4. responding to terrorist threats,

5. strategic commitments concerning terrorist threats (Cymerski, 2013).

Therefore, the strategy of the European Union can be divided into four pillars: preventing, protection, prosecution and responding.

Key elements in the field of preventing terrorist threats in the countries of the European Union are, as following:

- development of a common approach in terms of identification and combating problematic behaviour,

- solution of an issue on incitement and recruitment, especially in the environment such as prison, places of worship or religious education through introducing laws recognizing such behaviour as crime,

- creation the strategy for media and communication policy allowing to familiarize journalists with the Union policy,

- promotion of democracy, education and economic well-being through aid programmes of both the European Union and the Member States,

- development of intercultural dialogue inside the Member States of the EU and outside them,

- drawing up of a neutral/an impartial language in favour of pursuing the discussion concerning the above mentioned issues,

- continuation of studies, exchange of analyses, skill-sharing in order to understand the above mentioned problems more deeply and draw up political response (Cymerski, 2013). 
Protection of the potential targets of terrorist attempts is a key element in the fight against terrorism which needs to be strengthen by the minimizing effects of the attempts, limiting susceptibility to attack and protection of the external borders.

Priority activities in terms of protection include:

- implementation of improvements concerning European Union passport security through introduction of the biomedical data,

- development of the Visa Information System (VIS) and the second generation Schengen Information System (SIS II),

- performing of a risk analysis regarding the EU's external borders,

- implementation of common standards agreed concerning civil aviation safety, port and maritime security,

- adjustment of European programme in favour of protection of infrastructure of strategic importance,

- the best possible use of research works at the level of the European Union and the European Economic Community (Cymerski, 2013).

Instruments belonging to the category of an European Arrest Warrant are to be important tools for prosecution. Prosecution deals with dismantling any terrorist networks, terrorist groups, preventing them from preparing a terrorist attempt and as well as bringing to justice of the alleged perpetrators. Actions relating to prosecution include:

- making use of Eurojust and Europol to enhance cooperation between judicial and police authorities in order to develop a joint assessment of the phase of terrorist threat,

- development of cooperation of the criminal justice system,

- preventing of the access to explosives and weapon, starting from elements necessary to construct homemade bombs to biological, chemical, radiological and nuclear materials.

- assurance of full implementation of the currently applicable legal solutions and recognition of the international conventions and treaties,

- blocking of external financing for terrorist phenomena,

- guaranteeing of the technical assistance serving the increase of potential of third countries.

Responding requires joint operation of each Member State of the EU. The European Union should take all possible measures in case of the terrorist attack on one of the Member States, realizing that this can affect other states of the Union.

The strategy, in that regard, primarily include:

- correction of union mechanisms caring about protection of the citizens,

- development of a risk assessment of threats as a tool of creating Union abilities to response at the time of the terrorist attacks (a coordinated, uniform system of a rapid alert and response - ARGUS is to be responsible for this),

- improvement of the coordination with international organizations in the context of responding to terrorist attacks and other disasters,

- exchange of the best practice and development of agreements in order to provide victims of terrorist attacks and their families with aid" (Aleksandrowicz, 2008).

Cooperation of the states belonging to the European Union in the fight against terrorism is a necessity because it is a duty of each Member State. Combating terrorist groups and counteracting attacks in the EU must respect human rights and the principles of democracy. 


\section{COMBATING TERRORISM IN THE POLISH SAFETY POLICY}

Being a member state of the NATO military alliance and the European Union contributes to an improvement in the feeling of security of the member states although it does not guarantee this. Hence, many experts claim that Poland's membership in NATO and the EU is a threat from the phenomenon of terrorism. Poland is not recognized as the main target of terrorist strikes, however, the fact that there is a real danger and threat cannot be excluded.

Thus the Republic of Poland has not taken any action which could threaten any other country. Nevertheless, sources of threats need to be noticed in our surroundings. This was because Poland as a devoted ally of the United States of America participating in military missions and anti-terrorist action, involved in Afghanistan and the Persian Gulf, a significant country of the European Union, and a country, full of its internal conflicts and disputes, is vulnerable to terrorist attacks.

There are a few reasons why Poland is facing the threat of terrorism.

The most important ones include:

- global character of the international terrorism. Our country is not an isolated island and it is difficult to say that has a peculiar immunity protecting from this threat $\mathrm{Bu}-$ kowski, 2010);

- change of Polish foreign policy. Mainly, joining NATO, normalizations of the relations with Israel, participation in an anti-terrorist coalition, Poland's military involvement in stabilization missions in Afghanistan and Iraq cause that there are clear threats for Poland from Arab fundamentalists (Lonca, 2005);

- the opening of borders, that is, uncontrolled migration of people and contraband;

- creation of civil society and liberalization of regulations, which means that a state does not control all the spheres of social life. There is an opportunity to create structures which may serve the aims of the terrorists (Cupryjak, 2005);

- increase in the number of individuals isolated from the society, mostly badly educated and creating clans of Caucasian refugees who are a breeding ground for activity of criminal groups and Islamic radicals (Cymerski, 2013);

- membership in the European Union;

- alliances, especially with the USA and pro-western policy;

- media information of secret CIA prisons operating in Poland;

- a project of construction of the American anti-missile shield installations.

Poland's involvement in military operations in Afghanistan and Iraq caused that we became participants of the asymmetrical clash and thanks to this, our current threat level is increasing significantly. Despite the fact that conflict is taking place far from our borders, it should be borne in mind that asymmetrical action can occur in the territory of our country (Bukowski, 2010).

Apart from the above mentioned factors connected with the international political and military situation, factors resulting from the internal situation of our country should be pointed out. These include:

- economic difficulties resulting in deterioration of budgets of ministries responsible for shaping the state policy of safety,

- an imperfect system of combating terrorism for which the main weakness is the lack of coordinating particular components resulting primarily from the lack of organizing 
of the improvement and coordination training, especially at the highest levels of the command and control structures, including the Councils of Ministers,

- a lack of the clearly defined competences and division of tasks of people who function in the command units as well as operating procedures in special crisis situations (Cymerski, 2013).

As a result, one can state that Poland is threatened by mainly international terrorism resulting from the involvement of our country in the fight with the terrorism in the world and the change of form of the contemporary terrorism which changes from the local one into the global one. Apart from this, there is also a threat of internal terrorism which results from activity of criminal groups dealing with smuggling and proliferation of weapons of mass destruction.

It cannot be excluded either that criminal organizations making use of terrorist activity will force the government administration, self-government one and non-government organizations to issue specific decisions aiming at adoption of legal solution beneficial for the given organization or appointment of their own people for the appropriate positions.

The most serious signals of terrorist threats in Poland include:

1. In July 2003, a signal/message was received concerning the plans of the bomb attack in Marriott Hotel in Warsaw, a few days later there was a terrorist attack in one of the Marriott hotels in Malaysia (Wójcikowski, 2007);

2. In November 2003, Internal Security Agency (ABW) got the most serious information. Terrorist attacks on "Jews and the Crusaders" were planned between Christmas and New Year. Synagogues and churches in big cities in the whole Poland were to be targets of the attacks. The signal started the operation "Sword". Within the framework of this operation ABW monitored behavior of the groups of foreigners who appeared in the western regions of Poland . There were: a Libyan, a Lebanese and a stateless person. An Algerian was probably a coordinator of this action. They behaved as if they were trained officers of the intelligence service. They used so called counter observation, they phoned from pre-paid mobile telephones, which they had bought just before phoning and used them only for a few hours. According to $\mathrm{ABW}$, their visit had a connection with the planned terrorist attacks. The agency states that they managed to prevent these attacks, however, it did not reveal any details (Wójcikowski, 2007).

3. In the first days of April 2004, signals of highly probable terrorist attempts in the territory of our country occurred. They indicated that one of the leaders of Al-Qaeda was coming to carry out terrorist attacks in Poland and Ukraine. They suggested the reality of the attacks during the European Business Forum in Warsaw in April, 2004 and attacks at the time of so called the March of the living in Oświęcim . I was recognized that a potential terrorist act in the territory of our country might be (Cymerski 2013) prepared and conducted only with the support of external forces and Islamist extremists living in Poland. That threat ended with assumptions and forecasts (Lonca, 2005).

Taking into account the possibility of occurrence of the terrorist threats, legal regulations facilitating prevention of these threats are applied. This area, in case of the Republic of Poland, was regulated by the Constitution of the Republic of Poland and subordinate acts.

The Article 228 of the Constitution states that "in situations of particular threats if the ordinary constitutional measures are not sufficient, an appropriate state of Poland Emergency: martial law, a state of emergency, a state of natural disaster may be introduced" 
(Konstytucja RP z dnia 2 kwietnia 1997 r.). Consequently, terrorist attacks may cause the above mentioned states of emergency.

The Article 146 of the Constitution states that "within the scope and on the principles defined in the Constitution and law of the Council of Ministers ensures the internal security of the state and public order of the state" (Konstytucja RP z dnia 2 kwietnia 1997 r.).

The importance of a terrorist threat in Poland was noticed in the National Security Strategy of the Republic of Poland adopted by the Council of Ministers on $4^{\text {th }}$ January 2000 (Bukowski, 2010). Napisane jest tu, że nawet geograficzne oddalenie Polski od źródeł zagrożeń nie zapewni bezpieczeństwa. It says here that even Poland's remote location from the sources of threats do not ensure security. The strategy describes tasks of the government services that aims at ensuring and maintaining security, among other things, protection of independence of the Republic of Poland, protection of sovereignty, and maintaining territorial integrity and inviolability of its borders.

Our country is a signatory of many contracts, conventions and international agreements concerning counteraction of the terrorist threat. The counter-terrorism conference of 16 states of the regions of East Europe and South-Eastern Europe on $6^{\text {th }}$ November 2001 should be undoubtedly recognized as the most important initiative in this sphere of the action. Thanks to the ACTION PLAN adopted during that conference, a wider regional cooperation was established. It included, among other things, applying uniform procedures for combating terrorism, money laundering, applying uniform procedures for customs and passport control, fighting illegal migration (Mickiewicz, 2005).

Table 1. International Treaties in the field of combating terrorism, to which Poland is a party

\begin{tabular}{|c|c|c|}
\hline Type of the agreement & The date of the conclusion & $\begin{array}{l}\text { The scope of activities related } \\
\text { to the fight against terrorism }\end{array}$ \\
\hline \multicolumn{3}{|c|}{ International Treaties } \\
\hline $\begin{array}{l}\text { Treaty between the Republic of } \\
\text { Poland and the Federal Repub- } \\
\text { lic of Germany on good neigh- } \\
\text { borliness }\end{array}$ & 17.06 .1991 & $\begin{array}{l}\text {,(...) the contracting parties } \\
\text { will cooperate in respect of } \\
\text { combating organized crime, } \\
\text { terrorism (...)": Art. } 33 \text {. sec. } 2\end{array}$ \\
\hline $\begin{array}{l}\text { Agreement between the Re- } \\
\text { public of Poland and the Czech } \\
\text { and Slovak Federal Republic } \\
\text { on good neighborliness, soli- } \\
\text { darity and friendly cooperation }\end{array}$ & 04.05 .1992 & $\begin{array}{l}\text {,(..) the contracting parties } \\
\text { will cooperate in respect of } \\
\text { combating organized crime, } \\
\text { terrorism }(\ldots) " \text { : Art. } 20 . \text { sec. } 2\end{array}$ \\
\hline $\begin{array}{l}\text { Treaty between the Republic of } \\
\text { Poland and Ukraine on good } \\
\text { neighbourliness, friendly rela- } \\
\text { tions and co-operation }\end{array}$ & $\begin{array}{l}\text { 18.05.1992 (came into } \\
\text { force 30.12.1992) }\end{array}$ & $\begin{array}{l}\text {,(...) the parties will cooperate } \\
\text { in respect of combating orga- } \\
\text { nized crime, terrorism (...)": } \\
\text { Art. } 16 . \text { sec. } 2\end{array}$ \\
\hline $\begin{array}{l}\text { Treaty between the Republic of } \\
\text { Poland and the Republic of } \\
\text { Lithuania on friendly relations } \\
\text { and neighbourly cooperation }\end{array}$ & $\begin{array}{l}26.04 .1994 \text { (came into } \\
\text { force } 26.11 .1994)\end{array}$ & $\begin{array}{l}\text {,(...) the parties will cooperate } \\
\text { in respect of combating orga- } \\
\text { nized crime, terrorism (...)": } \\
\text { Art. } 24 \text {. sec. } 2\end{array}$ \\
\hline $\begin{array}{l}\text { Treaty between the Republic of } \\
\text { Poland and the Russian Feder- } \\
\text { ation on friendly relations and } \\
\text { good-neighborly cooperation }\end{array}$ & 08.05 .1993 & $\begin{array}{l}\text {,(...) the parties will cooperate } \\
\text { in respect of combating orga- } \\
\text { nized crime, terrorism (...)": } \\
\text { Art. } 16 \text {. sec. } 2\end{array}$ \\
\hline
\end{tabular}

The source: (Mickiewicz, 2005). 
Table 2. International and Interdepartmental Treaties in the field of combating terrorism, to which Poland is a party

\begin{tabular}{|l|l|l|}
\hline \multicolumn{2}{|c|}{ International and Inter-departamental } \\
\hline $\begin{array}{l}\text { Agreement between the Ministry of the In- } \\
\text { terior of the Republic of Poland and the } \\
\text { Ministry of the Interior of the Kingdom of } \\
\text { Morocco relating to combating crime, ter- } \\
\text { rorism, drug trafficking. }\end{array}$ & 26.06 .1995 & $\begin{array}{l}\text { These agreements include: } \\
\text { - exchange of information of people, } \\
\text { events, models of documents and } \\
\text { objects which are fruits of crime; }\end{array}$ \\
$\begin{array}{l}\text { Agreement between the Government of the } \\
\text { Republic of Poland and the Government of } \\
\text { the Republic of Slovenia on cooperation in } \\
\text { fighting terrorism, organized crime, illegal } \\
\text { trade of narcotic drugs, psychotropic sub- } \\
\text { stances and their precursors. }\end{array}$ & 28.08 .1996 & $\begin{array}{l}\text { - reciprocal rules on the protection } \\
\text { of classified information exchanged; }\end{array}$ \\
\hline $\begin{array}{l}\text { Agreement between the Government of the } \\
\text { Republic of Poland and the Government of } \\
\text { the Republic of Hungary on cooperation in } \\
\text { combating terrorism, unlawful drug traf- } \\
\text { ficking and organized crime. }\end{array}$ & 15.05 .1996 & $\begin{array}{l}\text { - principles of undertaking joint ac- } \\
\text { carrying out authorities }\end{array}$ \\
\hline
\end{tabular}

The source: (Mickiewicz, 2005).

Acts of international law in the related issues which Poland has ratified include:

- United Nations International Convention for the Suppression of the Financing of Terrorism of $9^{\text {th }}$ December 1999 (Journal of Laws 2004, No. 263, Item 2620 - from $10^{\text {th }}$ April 2002 (All) / 26 October 2003 (RP);

- The European Convention on the Suppression of Terrorism of the Council of Europe, done in Strasbourg on 27 $7^{\text {th }}$ January 1977 (Journal of Laws 1996, No. 117, Item 557 - from $4^{\text {th }}$ August 1978 (All)/1 ${ }^{\text {st }}$ May 1996 (RP)

- The Application of Council Regulation (EC) No 2580/2001 of $27^{\text {th }}$ December 2001 on certain specific "restrictive measures" against certain persons and entities aiming at combating terrorism (Journal of Laws UE L, No. 344, Item 70, with the later amendments from $28^{\text {th }}$ December 2001 (UE) / $1^{\text {st }}$ May 2004 (RP).

The Republic of Poland in their organizational structures worked out a system concerning combating terrorism, which is based on four stages: exploration, counteraction, combating, consequence management. Appropriate entities, services, offices of the government administration, collective advisory and opinion-making bodies are responsible for each area.

Exploration consists in observing activity of individuals or groups who may use terrorist methods in order to achieve actions of a political basis. Internal Security Agency (ABW), Intelligence Service Agency (AW), Military Information Services (WSI), the Military Intelligence Service, the Military Counterintelligence Service, the Special Services Committee and the Central Coordinating Team of Operational and Exploratory Activities in relation to Counteracting Political Terrorist Activity are the main institutions which are responsible for detection and identification terrorist threats.

Counteraction consists in preventing groups or individuals from using terrorist methods. It cannot exist without exploration, because the exploration may lead to identifying and taking appropriate security measures. Preventive activities can be also distinguished in 
counteraction. The state institutions dealing with counteraction include: the above mentioned special services, that is, ABW, AW, WSI, as well as the Government Protection Bureau (BOR), the police and the Border Guard. On the other hand, non-government organizations are internal services which prevent from a terrorist attack, and different security agencies.

In terms of counteraction, the Interministerial Centre for the Fight against Organised Crime and International Terrorism at the Ministry of Interior and Administration, formed in 2002, played a very important role in the system of counteracting against terrorism in Poland. It was appointed pursuant to the Ordinance No. 54 of the Prime Minister dated $30^{\text {th }}$ April 2002 (not published in the Official Journal). It is a basic institution which coordinates counterterrorist activities in Poland (http://www.terroryzm.com/system-przeciwdzialaniaterroryzmowi-w-polsce/).

The tasks of the Centre concerning the issue of the prevention of terrorism include: monitoring terrorist acts, making analyses and assessment of these acts and presenting conclusions and opinions, setting directions for programmes against terrorist acts, preparing operations with the use of means of transport, dedicated premises and possessing operational capabilities.

Combating consists in elimination of the groups or individuals that apply terrorist methods. Combating as well as counteraction, is connected with exploration, but in case of combating, a terrorist attack should occur/take place. There are different measures that may be taken to combat terrorism in the system of counter-terrorism in Poland. Apart from the physical aspect of combating terrorism, namely typical forcible measures, there are also formal and legal ones. In terms of combating, all the actions aimed at caching and arresting the perpetrator of the acts of terrorism need to be contained.

The services responsible for combating terrorism include: police forces together with anti-terrorist sub-units, Internal Security Agency (ABW), Intelligence Service Agency (AW), Military Information Services (WSI), special military units, Polish Air Force (in order to defend the air border), the Board Guard (to protect the state border), the General Inspectorate of Financial Information, the Customs Service.

In the Polish General Police Headquarters, they established the Bureau of Counter Terrorist Operations which consists of 175 police officers and tackles physical elimination of threats connected with terrorism (but its main task is the fight against criminal terrorism) (http://www.terroryzm.com/system-przeciwdzialania-terroryzmowi-w-polsce/).

Consequence management involves leading the rescue action and protecting against the secondary attack, that is, physical elimination of the effects. A threat of terrorist attack is connected with the crisis management problems. Crisis management concerns both at the district level (poviat in Poland) and the provincial level. A voivode is responsible for operating Crisis Management Centers at the provincial level but a foreman or a president of the city at the district level.

Thus, central and self-government administration has an influence on the emergency. Moreover, Crisis Management Centers prepare scenarios of potential terrorist attacks . During the crisis caused by a terrorist attack, a Command for Emergency Response is appointed, where the most significant political decisions are taken with respect to activities which aims at eliminating effects of the attack.

The Police Forces, The State Fire Service, National Defence, medical services, volunteers and the Armed Forces of the Republic of Poland also deal with elimination of effects of the terrorist attack. 
According to the internal legal regulations of the Republic of Poland, a terrorist threat may cover all fields of state activity, but it cannot be combated effectively by one service or one Ministry.

Efficiency of terrorism prevention is connected with an appropriate operation of the military sub-system, the non-military one and the management system based on legal formal and legal grounds, aimed at exploration, of threats, counteracting and combating them and consequence management of terrorist acts (Bukowski, 2010).

These undertakings involve a wide range of activities, which aim at the neutralization of the threat of a terrorist attack.

Szlachter, in his book, writes that an analysis of the system of preventing and combating terrorism, arising in Poland, allows one to say that our country has appropriate potential, which may serve effective counteraction against the phenomenon which threatens not only Poland but also all members of the international community. However, a lot of effort is required to create a system of coordination which enables to make use of this potential (Szlachter, 2007). As a result, there is a need of cooperation and coordination of all the subjects responsible for security. This cooperation should serve to monitor and combat threats of terrorism, benefiting from the experience of foreign alliances.

\section{CONCLUSIONS}

Taking into account the previous considerations, it is concluded that issues connected with combating terrorism are and will be a permanent/fixed element of the security policy of the Republic of Poland and the European Union. When analyzing the events in Ukraine and in other world's volatile regions, one can state that at present fight with terrorism, independently, on the fact how this phenomenon is understood by certain entities subject to international law, will be a threat not only for particular countries but also for stability of the whole international system.

Although, according to experts, the adopted organizational and legal model of preventing the terrorist threat is not sufficient (System przeciwterrorystyczny w Rzeczypospolitej Polskiej), one should state that it fulfills all the basic criteria and its development connected with transnational structures is heading in the right direction.

\section{REFERENCES}

Aleksandrowicz, T.R. (2008). Terroryzm międzynarodowy. Warszawa.

Bukowski, S.Z. (2010). Terroryzm europejski. Geneza i wspótczesne zagrożenia. Słupsk: Wydawnictwo Naukowej Akademii Pomorskiej w Słupsku.

Cupryjak, M. (2005). Doskonalenie narodowego systemu przeciwdziałania terroryzmowi w kontekście wyzwań XXI wieku. Warszawa.

Cymerski, J. (2013). Terroryzm a bezpieczeństwo Rzeczypospolitej Polskiej. Warszawa: Oficyna Wydawnicza RYTM.

http://www.cbnt.collegium.edu.pl/index.php?option=com_content $\&$ view=article\&id=85:uniaeuropejska-wobec-terroryzmu-aktywno-midzynarodowa\&catid=34:analizy-i-raporty, As for: 18 April, 2014.

http://www.terroryzm.com/system-przeciwdzialania-terroryzmowi-w-polsce/, As for: 25 April 2014

http://www.uniaeuropejska.org/europol, As for: 22 April 2014. 
Kawula, S. (1999). Bezpieczeństwo człowieka i jego rodziny w społeczeństwie postmodernistycznym w Polsce [in:] Ciczkowski, W., ed., Bezpieczeństwo człowieka w środowisku lokalnym. Olsztyn.

Konstytucja Rzeczypospolitej Polskiej z dnia 2 kwietnia 1997 roku (Journal of Laws 1997, No. 78, item 483).

Lonca, R. (2005). Polska wobec obecnych zagrożeń terroryzmu globalnego [in:] Pływaczewski, E.W., ed., Przestępczość zorganizowana: Świadek koronny. Terroryzm. W ujęciu praktycznym. Kraków: Kantor Wydawniczy Zakamycze.

Maslow, H.A. (1986). W strone psychologii istnienia. Warszawa.

Mickiewicz, P. (2005). Polska w koalicji antyterrorystycznej - wnioski dla polityki bezpieczeństwa RP. „Zeszyty Naukowe Akademii Marynarki Wojennej” R. XLVI, nr 1(160).

Stefański, M. (2003). Sytuacyjne i podmiotowe uwarunkowania podejmowania interwencji policyjnej. Słupsk 2003.

System przeciwterrortystyczny w Rzeczypospolitej Polskiej, BBN, www.bbn.gov.pl/, [Access: 25.04.2014].

Szlachter, D. (2007). Walka z Terroryzmem w Unii Europejskiej. Toruń: Wydawnictwo Adam Marszałek.

Tomaszewski, T. (2001). Sytuacje i podmiotowe uwarunkowania. Warszawa: PWN.

Wójcicki, J.W. (2007). Przeciwdziałanie finansowaniu terroryzmu. Warszawa: Wolters Kluwer Polska.

DOI: 10.7862/rz.2019.mmr.23

The text was submitted to the editorial office: February 2019.

The text was accepted for publication: October 2019. 
